\title{
When Elephants Collide it is the Grass that Suffers: Cooperation and the Security Council in the Context of the AU/ICC Dynamic
}

\section{Dire Tladi}

Department of Public Law, University of Pretoria, Private bagX2o, Hatfield, Pretoria 0028, South Africa

diretladi2012@gmail.com

\begin{abstract}
Much has been written about the tension between the African Union and the ICc. Equally, the relationship between the ICC and the Security Council has received a significant amount of attention. Very often, the discourse has presented the debate a stand-off between the protagonist fighting the good fight and antagonists intent on wanton destruction. This article is concerned with the relationships between the ICC, AU and the Security Council. It argues that the relationships can be characterised as triangular conflictual relationship in which all three sides of the triangle are straddled by cooperation. The paper argues that all three entities, the ICC, the AU and Security Council are culpable in the use and abuse of cooperation against each other in the pursuit of narrow interests.
\end{abstract}

\section{Keywords}

ICC - AU - Security Council - cooperation - referral - deferral

\section{Statement of the Issues}

Perhaps no other issue has dominated the international criminal justice agenda as much as the tension between the African Union (hereinafter the $\mathrm{AU}$ ) and the International Criminal Court (hereinafter the ICC). The debate over the AU/ICC tension has been characterised by an ideological chasm that has pitted villains against protagonists - with both sides casting the other as 
villains intent on wanton destruction and themselves as the protagonists fighting the good fight. ${ }^{1}$

Although the source of the tension between the ICC and AU is multi-layered and complex, the ICC's relationship with the Security Council is certainly a key element of the tension. ${ }^{2}$ The Security Council's central role in the tension between AU and the ICC is evident particularly in relation to the ICC situations in Darfur and Libya, and less so, the situation in Kenya. All three situations indicate, to varying degrees, the influence that the Security Council can have on ICC operations and the tensions that can arise as a result of this influence. Those concerned with the influence that the Security Council has had on the

1 See for literature on ICC-AU relations, A. Abass, 'The Proposed Criminal Jurisdiction for the African Court: Some Problematical Aspects', 6o Netherlands International Law Review (2013), 27-50; D. Tladi, 'The African Union and the International Criminal Court: The Battle for the Soul of International Law', 34 South African Yearbook of International Law (2009), 57-69. For reflections on earlier, more positive relationship between the ICC and Africa, see S. Maqungo, 'The Establishment of the International Criminal Court: SADC's Participation in the Negotiations', 9 African Security Review (2000), 42-53. For exchanges between the AU and the ICC see letter dated 8 July 2013 from Hailemariam Desalagne, Prime Minister of Ethiopia and Chairperson of the African Union, and Dr Nkosazana Dlamini-Zuma, Chairperson of the African Union Commission, addressed to Judge Sang-Hyun Song, President of the International Criminal Court, in which the $\mathrm{AU}$ asserts that the proceedings against the Kenyan President and Deputy "may pose a threat to the ongoing efforts in the promotion of peace, national healing and reconciliation, as well as the rule of law and stability, not only in Kenya, but also in the Region" and the letter in response dated 5 August 2013, from Judge Song, in which he expresses the view that the Court is "bound by its mandate and legal framework, as detailed in its founding treaty, the Rome Statute" and that the "Court can only consider arguments raised in the context of the relevant judicial proceedings". See also further exchanges of letters dated 10 and 13 September respectively from the AU and the ICC (all letters on file with the author).

2 M. Weller, 'Undoing the Global Constitution: UN Security Council Action on the International Criminal Court', 78 International Affairs (2002), 693-712; M. Happold, 'Darfur, the Security Council and the International Criminal Court', 55 International and Comparative Law Quarterly (2006), 226-236; L. Condorelli and A. Ciampi, 'Comments on the Security Council Referral of the Situation in Darfur to the ICC', 3 Journal of International Criminal Justice (2005), 590-599. See also, in the context of the negotiations on the crime of aggression D. Tladi, 'Kampala, the International Criminal Court and the Adoption of a Definition of the Crime of Aggression: A Dream Deferred', 35 South African Yearbook of International Law (2010), 80-96, at 88-90. For an analysis of AU/ICC/Security Council relations, see T. Achiume, 'The African Union, the International Criminal Court and the Security Council' Background Paper, University of California, Irvine School of Law, ICC-UNSC Workshop, November 2012, available online at http://www.councilandcourt.org/files/2013/04/ICC-AU-UNSC-PositionPaper-FINAL.pdf (accessed 10 September 2013). 
work of the ICC point out that the Security Council is a political body with a political mandate, and to the extent that it influences the work of the ICC, it undermines the credibility and legitimacy of the ICC as an independent judicial institution - credibility that the ICC is particularly keen to preserve. ${ }^{3}$

Cooperation too has been a key feature in the tension between the AU and ICC. The AU has adopted several decisions calling on members, including States Parties to the Rome Statute of the International Criminal Court (hereinafter the "the Rome Statute") not to cooperate with the ICC in relation to the situations in both Darfur and Libya. ${ }^{4}$ There is a likelihood that, if Kenya were ever to

3 See authorities cited in note 2 above. Shortly after his election as Prosecutor of the ICC, the former Chief Prosecutor of the ICC, Mr Luis Moreno Ocampo, stated that the "ICC was totally independent and impartial", statement by Mr Luis Moreno Ocampo at the Ceremony for the Solemn Undertaking of the Prosecutor, Peace Palace, The Hague, 16 June 2003. In 2009, Ocampo described his duty as Chief Prosecutor as "to be impartial" and to "apply the law to massive crimes... without fear or favour", Keynote Address by Mr Luis Moreno Ocampo, Yale University, New Haven, 6 February 2009. Similarly, the current Prosecutor, shortly after her election, stressed that "the Prosecutor does not take into account any political considerations. These, we continue to say, belong to other institutions", Introductory Remarks by the Prosecutor-Elect during the International Conference: 10 Years Review of the ICC - Justice for All?, Sydney, Australia, 15 February 2012. The first President of the Court, Philippe Kirsch, suggested that the ICC was a response to the "bargaining away of justice" for "short-term political gain" approach, address by Judge Philippe Kirsch to the United Nations General Assembly, 30 October 2008. The current President of the Court, Judge Sang-Hyan Song, has stated that the Court offers something new "because it is independent of the United Nations and other political bodies", opening remarks by Judge Sang-Hyan Song during the Regional Conference on the International Criminal Court, Doha, Qatar, 24 May 2011. Cf., S.M.H. Nouwen and W.G. Werner, 'Doing Justice to the Political: The International Criminal Court in Uganda and Sudan', 21 European Journal of International Law (2011), 941-965; D. Kaye, 'Who is Afraid of the International Criminal Court: Finding the Prosecutor who can set it Straight', 90 Foreign Affairs (2011), 118-129. See, for a contrary view, D.M. Crane, 'The Bright Red Thread: The Politics of International Criminal Law - Do we Want Peace or Justice? The West African Experience', in L.N. Sadat (ed.) Forging a Convention for Crimes against Humanity (Cambridge University Press, Cambridge, 2011), at 59, who states as follows: "International criminal law is about politics. It is a naïve Chief Prosecutor who plans and executes his prosecution plan (if he or she has one) without keeping in mind the bright red thread of politics that permeates the entire existence of a tribunal or a court. Conceived due to a political event and creature of political compromise, politics is in the DNA of all the justice mechanisms that make up the modern era of international criminal justice."

4 See para. 10 of the Decision on the Meeting of African States Parties to the Rome Statute of the International Criminal Court (ICC), Assembly/AU/Dec.245(XIII), 3 July 2009; para. 5 of the Decision on the Progress Report of the Commission on the Implementation of Decision Assembly/Au/Dec.27o(VIV) on the Second Ministerial Meeting on the Rome Statute of the 
follow through on its threat to withdraw, a similar decision would be taken with respect to cooperation in respect of the Kenya trials. ${ }^{5}$ Several African States Parties, namely Kenya, Malawi, Chad, Nigeria and most recently the Central African Republic have heeded this call and have declined to cooperate in the arrest and surrender of a person under an ICC warrant. ${ }^{6}$ The Court in turn has issued decisions of non-cooperation against Malawi and two against Chad. ${ }^{7}$

International Criminal Court (ICC) Assembly/AU/Dec.296(Xv), 27 July 2010; para. 5 of the Decision on the Implementation of the Decisions on the International Criminal Court (ICC), Assembly/Au/Dec.334(XVI), 31 January 2011; paras 5 and 6 of the Decision on the Implementation of the Assembly Decisions on the International Criminal Court, Assembly/ AU/Dec.336(XVII), 1 July 2011; paras 7 and 8 of the Decision on the Progress Report of the Commission on the Implementation of the Assembly Decisions on the International Criminal Court, Assembly/AU/Dec.397(XVIII), 30 January 2012.

5 See on the Kenyan Parliament's decision to withdraw from the Rome Statute, Kofi Annan, 'Justice for Kenya', New York Times (9 September 2013), available online at http://www.nytimes .com/2013/o9/o9/opinion/justice-for-kenya.html?_r=3\& (accessed 10 September 2013). See also S. Maqungo, 'Kenya and the ICc: A tale of three mistakes and the cruellest gamble', The Iss Today (9 September 2013), available online at http://www.issafrica.org/iss-today/kenyaand-the-icc-a-tale-of-three-mistakes-and-the-cruellest-gamble (accessed 10 September 2013).

6 On 28 August 2013, for example, the President of the Assembly of States Parties sent out a notification to members of the Bureau of the Assembly of States Parties informing them that "Mr Abdel Raheem Hussein, Minister of National Defence of the Sudanese Government, visited the Central African Republic on 19 August" and that she had sent a letter to the Minister of Foreign Affairs of the Central African Republic, "reminding the government of the Central African Republic of its obligations as a State Party to the Rome Statute to cooperate with the Court" (e-mail message from the President of the ASP on file with the author, 28 August 2013). See also President of the Assembly calls upon the Government of Nigeria to respect its obligations under the Rome Statute, ICC Press Release of 16 July 2013 (ICC-ASP-20130716-PR933).

7 See, for discussion, D. Tladi, 'The ICc Decisions on Chad and Malawi: On Cooperation, Immunities and Article 98', 11 Journal of International Criminal Justice (2013), 199-221; Decision Pursuant to the Article 87(7) on the Failure of the Republic of Malawi to Comply with the Cooperation Requests Issued by the Court With Respect to the Arrest and Surrender of Omar Hassan Ahmed Al Bashir, Al Bashir (ICC-02/05-01/og), Pre-Trial Chamber I, 12 December 2011; Décision rendue en application de l'article 87-7 de le Statut de Rome concernant le refus de la République du Tchad d'accéder aux demandes de coopération délivrées par la Cour concernant l'arrestation et la remise d'Omar Hassan Ahmad Al Bashir. (ICC-02/05-01/og), Pre-Trial Chamber I, 13 December 2011. Decision requesting observations from the Republic of Kenya, Situation in Darfur, Sudan In the case of the Prosecutor v. Omar Hassan Ahmad Al Bashir (ICC-02/05-01/o9), 25 October 2013. See also Decision Pursuant to Article 87(7) on the Non-Compliance of the Republic of Chad with the Cooperation Requests Issued by the Court Regarding the Arrest and Surrender of Omar Hassan Ahmad Al-Bashir, in the Situation in 
A somewhat ambiguous decision has also been given in respect of Al Bashir's visit to Nigeria. ${ }^{8}$ Seen from this perspective, it is tempting to see cooperation as simply a victim of the tussle between the ICC and the AU. The situation is, however, slightly more complex. Cooperation, and how it is used, is in fact reflective of the broader political problem that flows from the complex and controversial legal relationship between the ICC and the Security Council. The problem can be described as a triangle of conflictual relationships between the African Union, the Security Council and the ICC, with cooperation straddling all three sides of the triangle.

The purpose of this paper is to assess the role of cooperation in the relationship between the main actors in the ICC/AU/Security Council triangle. I argue that in the jostling and posturing of these actors, cooperation, including creating obstacles for cooperation, is both used as a tool to achieve political objectives and also suffers as a victim of the posturing. The result, I argue, is the impoverishment of international criminal justice. I argue that, contrary to popular belief, none of the entities in the triangular relationships are free from blame. I begin by setting out the key elements of cooperation in the Rome Statute system. In the next section I consider the role of cooperation in the AU ICC tension. I then provide an assessment of the Security Council treatment of cooperation in ICC-related matters. I then offer some concluding remarks. Other issues, such as the immunity of heads of state of non-State Parties and the claim that the ICC is selective in its case selection, though relevant to the discussion, are not addressed in this article. ${ }^{9}$

Darfur, Sudan, The Prosecutor v Omas Hassan Ahmad Al Bashir (ICC-02/05-01/og), Pre-Trial Chamber, 26 March 2013. See also Decision Regarding Omar Al-Bashir's Visit to the Federal Republic of Nigeria, in the Situation in Darfur, Sudan, The Prosecutorv Omar Hassan Ahmad Al Bashir (ICC-02/05-01/09), 15 July 2013.

8 Decision on the Cooperation of the Federal Republic of Nigeria Regarding Omar Al-Bashir's Arrest and Surrender to the Court, in the Situation in Darfur, Sudan, The Prosecutor v Omar Hassan Ahmad Al Bashir (ICC-02/05-01/o9), 5 September 2013. In the context of its "discretionary power" and taking note of Nigeria's explanation for its failure to arrest Bashir, the Court decided not to refer the matter the Assembly of States Parties or the Security Council but did remind Nigeria of its obligation to arrest $\mathrm{Al}$ Bashir if a similar situation should arise in the future (in para. 13).

9 For an interesting assessment of the role of selectivity in the politics of the ICC, see J. Dugard, 'Palestine and the ICC: Institutional Failure or Bias?', 11Journal of International Criminal Justice (2013) 563-70; M. du Plessis, 'Universalising International Criminal Law - The International Criminal Court, African and the Problems of Political Perceptions', Iss Paper 249 (December 2013), available online at http://www.issafrica.org/publications/papers (accessed 10 June 2014). 
The obligation to cooperate with the Court is central to the success of the Rome Statute. As is often observed by states and in the literature, for example, the ICC does not have its own police force to arrest persons with outstanding arrest warrants. ${ }^{10}$ It is only states that can do this - although increasingly there is talk of using UN peacekeeping missions for this purpose. The centrality of cooperation for the effective functioning of an international criminal court was already foreseen by the International Law Commission in its work on the Draft Statute for an International Criminal Court. A Working Group of the Commission noted that "the effective functioning of the Tribunal would be dependent upon the international cooperation and judicial assistance of States."11 In a similar vein, the Assembly of States Parties routinely reaffirms the centrality of cooperation for the effectiveness of the Court. ${ }^{12}$ As Olson notes,

10 See, e.g., B. Swart, 'General Problems', in A. Cassese, P. Gaeta and J.R.W.D. Jones (eds) The Rome Statute of the International Criminal Court: A Commentary (Volume II) (Oxford University Press, Oxford, 2002), at 1589, who described the ICC as a "giant without arms and legs who needs artificial limbs to walk and work." See also A. Ciampi, "The Obligation to Cooperate', in A. Cassese, P. Gaeta and J.R.W.D. Jones (eds) The Rome Statute of the International Criminal Court: A Commentary (Volume II) (Oxford University Press, Oxford, 2002), at 1607. See further B. Swart, 'Arrest and Surrender', in A. Cassese, P. Gaeta and J.R.W.D. Jones (eds) The Rome Statute of the International Criminal Court: A Commentary (Volume II) (Oxford University Press, Oxford, 2002), at 1640.

11 See para. 1 of Commentary to Draft Article $5^{8}$ of the Working Group Draft Statute for an International Criminal Court, Report of the International Law Commission on the Work of Its Forty-Fifth Session (1993) Vol II(2) Yearbook of the International Law Commission, Annex (Report of the Working Group on a Draft Statute for an International Criminal Court), at 128. This language is reproduced in the Commentary to the final text of the Draft Statute. See para. 1 of the Commentary to Draft Article $5^{1}$ of the International Law Commission's Draft Statute for an International Criminal Court with Commentaries, 1994. It is interesting to note that the Commission adopted the unequivocal language "States Parties shall cooperate with the Court" notwithstanding the fact that some members of the Commission felt that this general obligation went too far. See para. 3 of the Commentary to Draft Article 51.

12 See, e.g., 2013 Assembly of States Parties Resolution on Cooperation, (ICC-ASP/12/ Res.3) which stresses, in the preamble, the "importance of effective and comprehensive cooperation and judicial assistance...to enable the Court to fulfil its mandate". Paragraph 3 of the same resolution emphasises this importance and adds that the failure to cooperate "has a negative impact on the [Court's] ability to execute its mandate." See also 2012 Assembly of States Parties Resolution on Cooperation (ICC-ASP/11/Res.5). See further para. 7-10 of the 2013 Assembly of States Parties Resolution on Strengthening the International Criminal Court and the Assembly of States Parties (ICC-ASP/12/Res.8). 
the "key to fighting impunity is robust enforcement". ${ }^{13}$ In the context of an international court such as the ICC, robust enforcement necessarily includes state cooperation with the ICC. If the ICC does not benefit from effective state cooperation, then the ICC cannot be effective in its mandate of fighting impunity. Put another way, the fight against impunity, in many respects, hinges on effective cooperation. It would be going too far to suggest that cooperation embodies the fight against impunity, but there is certainly a strong correlation between a commitment to the fight against impunity, on the one hand and cooperation, on the other hand.

In the light of the centrality of cooperation for the success of the ICC, the Rome Statute puts in place an elaborate regime on cooperation, underpinned by Article 86 which sets forth a general obligation on States to "cooperate fully with the Court in its investigation and prosecution of" Rome Statute crimes. The cooperation regime set forth in the Rome Statute contains detailed provisions on how requests for cooperation should be made and handled, ${ }^{14}$ provisions on arrest and surrender as a form of cooperation, ${ }^{15}$ as well as other forms of cooperation. ${ }^{16}$ The obligation to arrest and surrender, however, remains the key tool for cooperation and this is evidenced by the detail in which the Statute goes into in defining how this particular method of cooperation should function.

In response to the spate of cases of non-cooperation, the Assembly of States Parties to the ICC (hereinafter the "Assembly") has attempted to engage diplomatically to address the matter. In 2011 the Assembly adopted Assembly Procedures Relating to Non-Cooperation (hereinafter the "Procedures"). ${ }^{17}$ The Procedures identify two possible scenarios of non-cooperation. The first scenario relates to those cases, such as those at play in Chad and Malawi decisions, where the Court has referred a matter of non-cooperation to the Assembly, i.e., cases where judicial determination of non-cooperation has been made. The second scenario relates to those exceptional cases where the Court has not made a judicial determination of non-cooperation but "there are reasons

13 See L.M. Olson, 'Re-Enforcing Enforcement in a Specialised Convention on Crimes against Humanity: Inter-State Cooperation, Mutual Legal Assistance and the Aut Dedere Aut Judicare Obligation' in L.N. Sadat (ed.) Forging a Convention for Crimes against Humanity (Cambridge University Press, Cambridge, 2011), at 323.

14 Article 87 of the Rome Statute.

15 Articles 89, 90, 91 and 92 of the Rome Statute.

16 Article 93 of the Rome Statute.

17 Assembly Procedures Relating to Non-Cooperation contained in the Annex to document ICC-ASP/10/Res.5. 
to believe that a specific and serious incident of non-cooperation in respect of an arrest and surrender... is about to occur or is currently on going and urgent action by the Assembly may help to bring about cooperation."18

The first scenario would be handled through a formal response including public elements intended to facilitate dialogue. ${ }^{19}$ Although the text of the Procedures provide for the Assembly to have a plenary discussion, and "appoint a dedicated facilitator on a draft resolution containing concrete recommendations", the general thrust of the procedure for the first scenario appears to be directed at facilitating future compliance. ${ }^{20}$ Scenario two involves the use of regional focal points in order to "raise the issue [of non-cooperation] with officials from the requested State and other relevant stakeholders, with a view to promoting full cooperation." ${ }^{21}$

It is interesting to note that notwithstanding the number of cases of noncooperation that have already been submitted to the Court, to date, dialogue with a non-cooperating state has only been held on one occasion, in the case of Malawi, and this was not at the Assembly, as is foreseen in the Procedures, but rather in the Bureau - while Kenya has also appeared before the Bureau in the context of non-cooperation, this was prior to the adoption of the Procedures. ${ }^{22}$ Not a single dedicated facilitator has been appointed nor has a draft resolution containing concrete recommendations been the subject of negotiations. On the other hand, the more informal, diplomatic procedures under the second scenario have been used on every occasion of impending non-cooperation since the adoption of the Procedures. ${ }^{23}$ However, in each case where these procedures have been applied, the procedures were not able to prevent the anticipated non-cooperation. ${ }^{24}$

Some States Parties have also attempted to address the issue of non-cooperation through more creative means. Some European states have proposed the inclusion of language in the annual resolution of the Assembly on cooperation which purports to prohibit states from having "non-essential contacts" with

18 See para. 7 (b) of the Assembly Procedures on Non-Cooperation.

19 See, generally, para. 14 of the Assembly Procedures on Non-Cooperation.

20 Paragraph 14(f) of the Assembly Procedures on Non-Cooperation.

21 See para. 19 of the Assembly Procedures on Non-Cooperation.

22 See Report of the Bureau of the Non-Cooperation (ICC-ASP/11/19), 1 November 2012.

23 Ibid.

24 See, e.g., The Assembly Regrets Visit of Sudanese President to Chad of 20 February 2012, in which the President of the Assembly regrets "despite ICC orders and widespread calls by the international community for Chad to respect its obligations of cooperation with the Court, the visit of Omar-Al Bashir to Chad had taken place on 16 February 2013", ICC Press Release of 18 February 2013, (ICC-ASP-20130218-PR 874). 
individuals having outstanding ICC warrants of arrest against them. During the eleventh session of the Assembly, the Assembly could not agree on the proposal because some States Parties were concerned that this might be interpreted as creating a new obligation. ${ }^{25}$ This argument is not unreasonable. The Rome Statute already creates far reaching obligations on States Parties. ${ }^{26}$ States Parties may not be willing to accept obligations created by resolution without the benefit of the same level of scrutiny and exercise of political choice that would accompany the amendment of the Rome Statute. It may well be argued that the centrality of cooperation requires pragmatism and that practical solutions ought to be found for dealing with the problem of non-cooperation. However, the African Union and its interlocutors may find such arguments disingenuous since all their arguments about the political difficulties of indictments against heads of state are often met with the statement that the ICC applies law not politics. ${ }^{27}$ If the ICC applies only law and not politics, then surely States Parties should only be compelled to perform in terms of their legal obligations as found in the Rome Statute and not be expected to comply with duties deduced from pragmatic considerations. The Twelfth Assembly, as a compromise, agreed to a preambular paragraph noting that "contacts with person in respect of which an arrest warrant was issued by the Court is outstanding should be avoided where such contacts could undermine the objective of the Rome Statute."28

The Assembly Procedures on Non-Cooperation as well as the recent proposals for prohibiting non-essential contact with the indicted persons both take place within the context of, and in response to, the AU decisions that its members are not to cooperate with the ICC in respect of request for the arrest and surrender of sitting African heads of state. They are therefore, both an attempt to strengthen cooperation as well as a response to specific cases of non-cooperation. On the other hand, these various initiatives, to the extent that they seek to expand the obligations, may reflect the tendency to

25 It is not inconceivable that a resolution calling prohibiting non-essential contacts with persons under arrest warrants could be seen as "a subsequent agreement between the parties regarding the interpretation of the treaty" within the meaning of Article 31(3)(a) of the Vienna Convention on the Law of Treaties and in this way be read into the general obligation to cooperate.

26 See, e.g., para. 3 of the Commentary to Draft Article $5^{1}$ of the International Law Commission's Draft Statute for an International Criminal Court with Commentaries, 1994 where some members of the Commission took the view that a broad duty to cooperate beyond specific treaty requirements would be going "too far."

27 See ICc letters to the Au cited in note 5 above.

28 See preamble ICC Assembly Resolution on Cooperation Resolution ICC-ASP/12/Res.3. 
use the centrality of cooperation to go beyond the four corners of the Rome Statute. Certainly this would be the case for the consistent attempts to prohibit "non-essential contacts" with persons under outstanding ICC arrest warrants. The non-cooperation procedures, ostensibly designed to ensure cooperation, are directed at those cases in which States Parties, fully aware of their obligation, decide for politically sensitive reasons not to cooperate. The likelihood of these procedures having an effect on non-cooperation, beyond the effect of the Rome Statute itself, was always going to be slim. The procedures, therefore, appear to be more for publicity than to ensure cooperation.

The chronology of events surrounding the AU/ICC tension is discussed elsewhere and will not be fully recounted here. ${ }^{29}$ The events are recounted here only to the extent that they reveal something about the role that cooperation has played in the unfolding of this tension.

When President Al Bashir of Sudan and Colonel Muamar Gaddafi of Libya were indicted by the ICC and warrants for their arrest were issued and circulated, an obligation to arrest and surrender, as discussed in the previous section, arose. In both cases - although it should be stressed for different political reasons - the African Union barked at the idea of sitting African heads of nonStates Parties to the Rome Statute being prosecuted in an apparent violation of their head of state immunity. It is apposite to point out that in both cases the Court's involvement in Sudan and Libya - non-States Parties - occurred pursuant to Security Council resolutions in terms of Article 13(b) of the Rome Statute. ${ }^{30}$ Whether the fact that arrest warrants were in connection with a situation referred to the ICC by the Security Council impacted on the immunities is a matter of debate but falls outside the scope of this article. ${ }^{31}$ What is not a matter of debate is that there arose an obligation on States Parties to cooperate

\footnotetext{
29 See authorities cited in note 1 above.

$30 \quad$ UN Security Council Resolution 1593 (2005) and UN Security Council Resolution 1970 (2011).

31 See Tladi, supra note 7. For a different view, see D. Akande, 'The Legal Nature of the Security Council referrals to the ICC and its Impact on Al Bashir's Immunities', 7 Journal of International Criminal Justice (2009), 333-352. Cf., P. Gaeta, 'Does President Al Bashir Enjoy Immunity from Arrest?', 7 Journal of International Criminal Justice (2009) 315-332; C. Kre $\beta$, 'The International Criminal Court and Immunities under International Law for States not Party to the Court's Statute', in M. Bergsmo and Y. Ling (eds) State Sovereignty and International Criminal Law (Torkel Opsahl, Oslo, 2012), 223.
} 
with the Court "in accordance with the Statute". ${ }^{32}$ Moreover, both un Security Council resolutions required the situation countries, Libya and Sudan, to cooperate with the ICC. ${ }^{33}$

In response, and after the Security Council's refusal to defer proceedings against $\mathrm{Al}$ Bashir under Article 16, the AU adopted a decision on non-cooperation in 2009. ${ }^{34}$ That decision provided, in part, that "in view of the fact that the request by the African Union has never been acted upon, the AU Member States shall not cooperate... for ( sic) the arrest and surrender of President Omar El Bashir of The Sudan." This decision was followed up by several other decisions with more or less the same content. ${ }^{35}$ In 2010, a new paragraph requesting States Parties to balance their obligations under the Statute with the obligations to the $\mathrm{AU}$ was added to nuance the obligation slightly. ${ }^{36}$ Although the considerations with respect to Gaddafi were slightly different, the AU nonetheless in July 2011 adopted a decision to the effect that African States were not to cooperate with the ICC in respect of the arrest and surrender of Gaddafi. ${ }^{37}$

The AU's decision to withhold cooperation from the ICC is, in a sense, an attempt to strike the ICC 'where it hurts the most', namely cooperation. As a political statement it may even be seen as a form of political protest against the perceived oppression of Africa. Without cooperation from States, the indictments are, from a prosecutorial standpoint, worth very little. More to the point, the text of the decision sheds light on the triangle of conflictual relationships between the AU, ICC and Security Council. According to the text, the decision on non-cooperation in respect of Bashir is based on the failure of the Security Council to act on the AU's request for deferral. ${ }^{38}$ However, this

32 Article 86 of the Rome Statute.

33 See para. 2 of Resolution 1593(2005); see para. 5 of Resolution 1970(2011).

34 AU Summit Decision on the Meeting of African States Parties to the Rome Statute of the International Criminal Court (ICC), Assembly/AU/Dec.245(XIII), July 2009. This decision has been followed up with subsequent decisions on non-cooperation.

35 See, e.g., Decision on the Implementation of the Decisions on the International Criminal Court (ICC), Assembly/AU/Dec.419(XIX), July 2012.

36 See para. 6 of Decision on the Progress Report of the Commission on the Implementation of Decision Assembly/AU/Dec.270(xIv) on the Second Ministerial Meeting on the Rome Statute of the International Criminal Court (ICC) Doc. Assembly/AU/10(Xv), Assembly/ AU/Dec.296XV), July 2010 in which Member States were requested "to balance, where applicable, their obligations to the AU with their obligations to the ICC."

37 See para. 6 of the Decision on the Implementation of the Assembly Decisions on the International Criminal Court, Assembly/Au/Dec.366(XVII), July 2011.

38 AU Summit Decision on the Meeting of African States Parties to the Rome Statute of the International Criminal Court (ICC), Assembly/AU/Dec.245(XIII), July 2009. 
suggests that the quarrel of the AU is in fact not with the ICC but rather with the Security Council. If this is the case, it may well be asked why the sanctions for non-responsiveness to the AU are not directed against the Security Council. It may well be asked, for example, why the AU had not decided that members of the African Union will not participate in the Security Council, essentially making decision-making with the Council difficult while also reducing the legitimacy of any decisions that the Council would adopt. Instead, it is the ICC, in particular the obligation to cooperate with the ICC, that is made to suffer as a result of the differences between the AU and the Security Council, while relations between the AU and the Security Council proceed unaffected. The decision of the $\mathrm{AU}$, targeting the ICC, when the institution that is responsible for the non-response of its request is the Security Council may thus smack of disingenuity and double standards. ${ }^{39}$

However, it would be an oversimplification to characterise the AU decisions as lacking in legal merit. As is apparent from the more recent AU non-cooperation decisions, the $\mathrm{AU}$ decisions are purportedly also based on the immunities exception in Article 98 of the Rome Statute. ${ }^{40}$ Seen in this light, the AU decisions do not undermine the Rome Statute legislative framework but rather are an application of it. Article 98 of the Rome Statute provides an exception to the general obligation to cooperate where cooperation "would require the requested state to act inconsistently with its obligations under international law with respect to the State or diplomatic immunity." The AU has argued that there is no obligation on States Parties to arrest a head of state of a non-State Party since this would require the States to violate their international law obligations. ${ }^{41}$ Whatever the position under international law, what is difficult to deny is that the ICC Pre-Trial Chamber's decision, in its eagerness to enforce cooperation, failed to adequately address the legal question about cooperation and, in particular the exception in Article 98 of the Rome Statute, posed by the AU position and advanced by Malawi and Chad in the non-cooperation cases. ${ }^{42}$

39 The author has previously described the AU's decision of non-cooperation, and the political reasons on which it is based, as an "attempt to blind us from the truth." See Tladi, supra note 1 , at 69 .

40 See, e.g., para. 3 of Decision on the Implementation of the Decisions on the International Criminal Court (ICC), Assembly/AU/Dec.419(XIX).

See AU Commission Press Release on the Decision of the Pre-Trial Chamber of the ICC on Alleged Failure by the Republics of Chad and Malawi to Comply with the Cooperation Request issued by the Court with respect to the Arrest and Surrender of President Omar Hassan Al Bashir of the Republic of Sudan, 9 January 2012 in which the Commission describes the decision as "ill-considered" and "self-serving". 
Needless to say this only adds to the AU criticism of a politicised court that is not independent while at the same time diminishing the ICC's refrain of a Court that applies only law.

\section{4}

\section{Security Council and Cooperation}

As mentioned earlier, central to both situations in which the AU has called for non-cooperation, namely in the cases against Al Bashir and Gaddafi, has been the Security Council, in particular, because both cases are conducted by the ICC pursuant to a Security Council resolution. How the Council approaches cooperation in the referring resolutions, as well as subsequent to incidents of noncooperation, is an important element of the triangular relationship between the AU, ICC and Security Council on cooperation. However, the Security Council's role in the decision on non-cooperation of the $\mathrm{AU}$ is not limited to the actual referrals. It will be recalled that the $\mathrm{AU}$ decisions in relation to the $\mathrm{Al}$ Bashir arrest warrant were made "in view of the fact that the request by the African Union [to the Security Council under Article 16] has never been acted upon". ${ }^{43}$ Thus the treatment by the Security Council of requests for deferral of investigations and prosecutions under Article 16 is also relevant.

The Security Council resolutions referring the situations in Darfur and Libya to the ICC, resolutions 1593 and 1970 respectively, provide interesting insights into the Security Council's attitude to cooperation. While the two resolutions create an obligation on the situation country concerned, i.e., Sudan and Libya, to cooperate with the Court, it does not do so with respect to other Member States of the United Nations. ${ }^{44}$ As a result of this limited scope of the obligation to cooperation, only the situation countries are, as a matter of the respective resolutions, bound by the obligation to cooperate. States Parties, of course, are bound by the obligation to cooperate, but on the basis of the Rome Statute and not the respective resolutions. The result of this is that it can be argued, as the AU does (and as previously argued by this author), that the exception to the obligation to cooperate in Article 98 of the Rome Statute is applicable notwithstanding the fact that the Security Council referred the situations. ${ }^{45}$ In particular, I have previously argued that had the Council created a universal

\footnotetext{
43 See para. 10 of the Assembly/AU/Dec.245(XIII).

44 See para. 2 of UNSC Res 1593 (2005) and para. 4 of UNSC Res 1970 (2011).

45 See also Tladi, supra note 7 , at 208 and 212 et seq. See also Condorelli and Ciampi, supra note 2 , at 593 .
} 
obligation to cooperate, then any limitation implied by Article 98 of the Rome Statute would be trumped by the superior obligation of a Chapter VII Security Council resolution on the basis of Article 103. ${ }^{46}$ Thus, the limited scope of cooperation under the respective resolutions has at least contributed to the cases of non-cooperation by creating legally plausible avenues for non-cooperation.

Although the intention behind limiting the scope of the resolutions was certainly not to shield States Parties from the obligation to cooperate, the limited scope of the resolutions in question was not an oversight. The resolutions were adopted in this manner because the permanent members of the Security Council which are not party to the Rome Statute could not accept being subject to an obligation to cooperate with the ICC. Thus in both cases, narrow political interests of some members of the Security Council were an obstacle to a broad based obligation to cooperate which would have removed the ambiguities concerning the reach of Article 98. This may suggest that cooperation is not a priority to the Security Council and can be dispensed with in the interest of political considerations. Even worse, if cooperation is essential for the effectiveness of the Court, then depriving the Court of meaningful cooperation may suggest that the Security Council was, in fact, not interested in ensuring effective cooperation and effective justice and that rather, the Council sees referral of situations as a political tool designed to exert pressure on the situation country.

In addition to the limited scope of the obligation to cooperate, both resolutions also limit cooperation between the UN and the ICC in relation to the financing of investigations and prosecutions of situations referred to the ICC. Article 115 of the Rome Statute provides that funds "provided by the United Nations, subject to the approval of the General Assembly, in particular in relation to the expenses incurred due to referrals by the Security Council" are a source of funding for the ICC. ${ }^{47}$ However, both referring resolutions preclude the possibility of funding investigations and prosecutions arising from the referrals from UN resources. ${ }^{48}$ The compatibility of these exclusions with the uN Charter is, at least, questionable because under the Charter, financial and budgetary matters fall within the mandate of the General Assembly and not the Security Council. ${ }^{49}$ However, the Council adopts this approach principally

\footnotetext{
46 Tladi, supra note 7 , at 208.

47 See also Article 13 of the Relationship Agreement between the International Criminal Court and the United Nations of 2004.

48 See para. 7 of the UNSC Res 1593 and para. 8 of UnSC Res 1970.

49 See Article 17 of the 1945 Charter of the United Nations.
} 
because United States law and policy prohibits financing of the ICC. ${ }^{50}$ As with the narrow scope of the obligation to cooperate in the two referring resolutions, the exclusion of possible financial support for ICC investigations and prosecutions flowing from Security Council referrals suggests that the Security Council does not take investigation and prosecutions as a priority and perhaps viewed the referral of the respective situations as more of a political tool than a facilitation of justice and accountability.

The impression that referrals to the ICC are used by the Security Council as a political tool rather than efforts aimed at ensuring accountability seems corroborated by the Council's attitude towards non-cooperation, in both the situations in Darfur and Libya. The failure of the Council to act against Sudan for non-cooperation, as required in Resolution 1593, as well as the unwillingness to discuss cases of non-cooperation referred to it by the ICC signifies a lack of political will to ensure cooperation. ${ }^{51}$ Similarly, as of the writing of this article, Libya remains in non-cooperation with respect to the surrender of Saif Al-Islam Gaddafi, who is in the custody of the Libyan authorities. The Security Council has not taken action in respect of this non-cooperation, despite a clear decision by the ICC that Libya should cooperate in the surrender of Saif Gaddafi. ${ }^{2}$

Although Article 16 of the Rome Statute, concerning deferral, and the Council's failure to invoke it is at the source of the AU decision on non-cooperation, it does not relate directly to cooperation. Nonetheless, the manner that the Security Council has dealt with two requests for Article 16 deferrals may illustrates the complexity of the triangular relationship between the AU, ICC and Security Council. As mentioned earlier, the resolutions on noncooperation in relation to $\mathrm{Al}$ Bashir are prefaced by the phrase "in view of the fact that the request by the African Union [to the Security Council under Article 16] has never been acted upon". Similarly, the recently adopted AU decision in relation to Kenya, begins by "[d]eeply regret[ting] that the request

$5^{0}$ See, for discussions on us law and policy towards financing the ICC, J.K. Elsea, 'Us Policy Regarding the International Criminal Court', Congressional Research Service Report for Congress (14 June 2006), at 10.

51 In the author's view the Security Council would not have the mandate to deal with matters of non-cooperation by members states of the UN other than Sudan because the Security Council did not oblige other member States, including States Parties, to cooperate. Nonetheless, the fact that the ICC has referred these matters of non-cooperation, it was incumbent upon the Council to at least consider these even if it came to the conclusion that, because of the narrow scope of cooperation in resolution 1593, it could not act upon them.

See Decision on the request for suspensive effect and related issues, The Prosecutor v. Saif Al-Islam Gaddafi and Abdullah Al-Senussi (ICC-01/11-01/11), 19 July 2013. 
by the African Union" has not been acted upon. ${ }^{53}$ While in respect of the Bashir request there is some truth to this in that the Security Council never "acted upon" the request, at least not expressly, ${ }^{54}$ this is certainly not accurate in respect of the situation in Kenya. The first AU decision requesting an Article 16 deferral for Kenya was taken in January 2011. ${ }^{55}$ By April of the same year, the Security Council had held an interactive dialogue and two consultations on the matter. Moreover, the Security Council had issued an informal document referred to as Elements to the Press explaining that it had not reached consensus on an Article 16 deferral and had sent two letters, one to the African Union Permanent Observer and the other to the Permanent Representative of Kenya, repeating the elements to the press. ${ }^{56}$ In 2013, an equally robust consideration of the AU request for deferral of the Kenya cases resulted in a vote in the Security Council. ${ }^{57}$ This can be contrasted with the Security Council's lethargic approach to the AU's request for deferral of the Bashir investigation and prosecution. The first decision by the AU for a deferral in respect of Bashir was issued in 2008 - the decision is routinely reiterated by the AU. Yet to date, the only "consideration" by the Security Council of the request on Bashir was the proposal by South Africa and Libya in the context of the UNAMID resolution in 2008 and some exploratory, low level discussion between South African, French and British diplomats on what, hypothetically, could be contained in an Article 16 deferral resolution for Bashir. ${ }^{58}$

53 See AU Summit Decision on International Jurisdiction, Justice and the International Criminal Court (ICC), Assembly/Au/Dec.9(XXI), May 2013.

54 This is however, only partly true since in 2008 , in the context of consultations on a draft resolution on the extension of the mandate of the UN Mission in Darfur, South Africa and Libya proposed deferral language. France, the United States and the United Kingdom did not accept the language. As a compromise, UN Security Council Resolution 1828 (2008) noted the request of the $\mathrm{AU}$ "regarding potential developments subsequent to the application of the Prosecutor" and also expressed its "intention to consider these matters further."

55 See para 6 of the AU Summit Decision on the Implementation of the Decisions on the International Criminal Court (ICC), Assembly/AU/Dec.334(XVI), January 2011.

56 See Security Council Report's chronology of events on Kenya, available online at http:// www.securitycouncilreport.org/chronology/kenya.php (accessed 11 September 2013).

57 See Draft Resolution S/2013/66o (not adopted, seven votes for, zero against, 8 abstaining). See per verbatim record of the 706oth Meeting of the Security Council, 15 November 2013 (s/Pv/706o).

$5^{8}$ These discussions focused on three aspects. First, what conditions would need to be placed in the resolution to ensure that it was not a 'blank cheque'. Second, whether the conditions would have to be met before the Article 16 deferral is granted, i.e., two resolutions, the first of which would put in place the conditions and the second of which would confirm that the conditions had been met and thereby activate the Article 16 
The differences in the attitude to the two requests may be best understood in the light of the arguments raised for not acceding to the AU's request on Kenya in 2011. ${ }^{59}$ For the most part, members of the Security Council, including those sympathetic with Kenya, did not find that Kenya's request, as a matter of law, fell within the Security Council's competence and the parameters of Article 16. Article 16, it was argued by most delegations, contemplated the Security Council acting in matters related to the maintenance of international peace and security while the Kenyan request seemed more related to questions of complementarity, i.e., Kenya's argument seemed to be that, in accordance with the principle of complementarity, it should be permitted to conduct its own investigations and prosecutions. ${ }^{60}$ The majority of the members of the Security Council thus took the view that the matter was not properly before the Council and should rather be dealt with by the ICC in accordance with its judicial processes. The same argument could not be made with respect to the request to defer Bashir-related prosecution. There was, in the case of Bashir, a clear link between a potential deferral and international peace and security whether this link as a matter of fact justified a deferral is a different matter. The Security Council's eagerness to consider the Kenyan request while at the same rejecting any attempt to "formally" consider the same request in the case of the Bashir related request may thus be partly explained by the fact that it would be much easier to, on the basis of the Rome Statute itself, reject the Kenyan request, while considering the Bashir related request would prove more challenging. From the perspective of cooperation, this unequal treatment of two requests for deferral may show how the Security Council is able to skilfully rely on the "law" when it suits it, e.g., with Kenya, and avoid dealing with a situation when the law and the political objectives are not in line - Bashir.

or whether the Article 16 deferral would be put in place immediately with its renewal dependent on meeting the requirements. Finally the discussions focused on what one participant referred to as the "end-game", i.e., whether the Article 16 deferral would be renewed indefinitely or whether, at some point, it would be lifted notwithstanding Sudan's cooperation. In other words, what would happen when Sudan became stable and free from conflict? The reason for the Article 16 deferral would no longer exist. Would the Article 16 be resolution be renewed nonetheless (reward) or would it be lifted (in pursuit of justice)?

59 Although I am unable to ascribe specific views to different delegations due to the fact that the meetings took place in private meetings of the Security Council, I am able to say that of the fifteen members of the Security Council only one member supported the request of Kenya for an Article 16 deferral of the cases in Kenya in 2011.

6o It should be noted that in the face of the views expressed by members of the Security Council, Kenya has morphed its position to one that makes more prominent peace and security issues. However, this is probably more cosmetic than real. 
The cooperation of States is one of the most central features of the ICC system. Without cooperation, the Court cannot conduct effective investigation and it can certainly not have trials. And yet cooperation has been the victim of a tug of war between the role players meant to give effect to, i.e., states, the ICC itself and other international entities such as the AU and the Security Council. It has been used by these entities as a political tool to be used and discarded at will. The AU, principally because of its overt decision that its members shall not cooperate with the ICC in arrest and surrender of heads of state, has taken the brunt of the blame for the abuse of cooperation. What has not received adequate attention is the role that others have played in undermining and misusing cooperation. Key amongst these has been the Security Council which has referred situations to the ICC but has undermined the principle of cooperation for narrow political interests of some of its permanent members through a various means including severely limiting the scope of cooperation, purporting to prevent the UN from financing investigation of situations referred to by the Council and for not acting in cases of non-cooperation. The ICC itself has at times harmed the objective of cooperation. The ongoing attempts at expanding the scope of cooperation beyond what is contemplated in the Statute to include the prohibition of "non-essential contacts" as well as the failure of the Court to address, head on, legal arguments presented in cases of non-cooperation adds fuel to the charge that the ICC is an active participant in the politics and legitimise cases of non-cooperation.

Like the grass that suffers when elephants fight, cooperation, and with it, the objectives of the Rome Statute to ending impunity and ensuring accountability, are suffering due to the political differences between the AU, the ICC and the Security Council. For the sake of justice, the elephants must show leadership and a willingness to cooperate in the pursuit of peace and justice.

\section{Acknowledgements}

I thank the participants at the Workshop on the Future of International Law in Africa, held on 20 September 2013 in Pennsylvania as well as the comments of the anonymous reviewers that commented on the paper. The views expressed herein do not necessarily reflect the position of the Government of the Republic of South Africa. 